\title{
A new syndrome of autosomal recessive nephropathy, deafness, and hyperparathyroidism
}

\author{
B D EDWARDS*, M A PATTON†, S A DILLY , AND J B EASTWOOD* \\ From the Departments of Medicine*, Geneticst, and Histopathology $\ddagger$, St George’s Hospital Medical School, \\ Cranmer Terrace, London SW17 ORE.
}

SUmmary A consanguineous Pakistani family is described in which family members developed renal failure without haematuria, parathyroid hyperplasia, and sensorineural deafness. We believe the condition to be inherited as an autosomal recessive and to be distinct from Alport's syndrome, which is an $\mathrm{X}$ linked condition usually associated with haematuria.

The association between renal disease leading to renal failure and sensorineural deafness was first reported by Hurst $^{1}$ in 1923 . Shortly afterwards, Alport ${ }^{2}$ described in more detail the syndrome that bears his name. Neither Alport's syndrome nor any of the other lesser known hereditary syndromes linking deafness with renal disease has ever been associated with hyperparathyroidism. ${ }^{3}{ }^{4}$ We have recently studied a family in which two sibs developed parathyroid hyperplasia, sensorineural deafness, and renal failure.

\section{Case reports (table, fig 1)}

\section{CASE III.5}

An 11 year old Pakistani boy presented in March 1975 with nocturnal enuresis and thirst. On examination he was of normal stature but clinically anaemic. Investigations showed fasting calcium $2.9 \mathrm{mmol} / \mathrm{l}$, phosphate $1.67 \mathrm{mmol} / \mathrm{l}$, alkaline phosphatase 40

Received for publication 5 July 1988.

Revised version accepted for publication 21 October 1988.
IU/l, urea $10.4 \mathrm{mmol} / \mathrm{l}$, creatinine $310 \mu \mathrm{mol} / \mathrm{l}$, creatinine clearance $11 \mathrm{ml} / \mathrm{min}$, haemoglobin $10 \cdot 0$ $\mathrm{g} / \mathrm{dl}$, and ESR $57 \mathrm{~mm}$ in one hour.

The hypercalcaemia was not abolished by a 10 day course of oral prednisolone $30 \mathrm{mg} /$ day. Serum parathyroid hormone (PTH) was $1.5 \mathrm{ng} / \mathrm{ml}$ (normal $<0.73$ ). Urine examination showed protein ' $t$ '. The urine was free of cells and sterile on culture. Xerogram of the neck was negative. Nevertheless, a provisional diagnosis of autonomous (primary) hyperparathyroidism was made. Neck exploration showed four enlarged parathyroid glands of which three and a half (combined weight $310 \mathrm{mg}$ ) were removed. Histology showed chief cell hyperplasia. Postoperative hypocalcaemia was corrected using dihydrotachysterol.

Because of continuing unexplained renal failure, renal biopsy was performed. Light microscopical examination showed diffuse glomerular tuft sclerosis with capsular fibrosis, and electron microscopy showed occasional splitting of the basement membrane with scattered, small, dark intramembranous

TABLE Clinical and laboratory findings at presentation.

\begin{tabular}{|c|c|c|c|c|c|c|c|c|}
\hline & \multirow{2}{*}{$\begin{array}{l}\text { Serum } \\
\text { urea } \\
(\mathrm{mmol} / \mathrm{l})\end{array}$} & \multirow{2}{*}{$\begin{array}{l}\text { Serum } \\
\text { creatinine } \\
\text { ( } \mu \mathrm{mol} / \mathrm{l})\end{array}$} & \multirow{2}{*}{$\begin{array}{l}\text { Serum } \\
\text { calcium } \\
(\mathrm{mmol} / \mathrm{l})\end{array}$} & \multicolumn{2}{|c|}{ Midstream urine } & \multirow{2}{*}{$\begin{array}{l}\text { Creatinine } \\
\text { clearance } \\
(\mathrm{ml} / \mathrm{min})\end{array}$} & \multirow{2}{*}{$\begin{array}{l}\text { Renal } \\
\text { failure }\end{array}$} & \multirow[t]{2}{*}{ Hearing loss } \\
\hline & & & & Red cells & $\begin{array}{l}\text { Urinary } \\
\text { protein }\end{array}$ & & & \\
\hline Father II.1 & $5 \cdot 7$ & 115 & $2 \cdot 47$ & 20 & + & - & - & No \\
\hline Mother II.2 & $7 \cdot 8$ & 96 & $2 \cdot 29$ & 0 & 0 & - & - & No \\
\hline III. 2 & $7 \cdot 8$ & 97 & $2 \cdot 29$ & 0 & 0 & - & - & Yes \\
\hline III. 3 & 10.9 & 324 & 3.84 & $<5$ & $0.55 \mathrm{~g} / 24 \mathrm{~h}$ & 14 & + & Yes \\
\hline III.4 & $17 \cdot 0$ & 304 & $2 \cdot 90$ & $<5$ & + & 11 & + & Yes \\
\hline III. 5 & $12 \cdot 8$ & 396 & 1.41 & $<5$ & ++ & - & + & Yes \\
\hline III. 6 & $5 \cdot 5$ & 78 & $3 \cdot 33$ & 0 & 0 & - & - & Yes \\
\hline Normal values & $\begin{array}{l}2 \cdot 5- \\
6 \cdot 5\end{array}$ & $\begin{array}{l}42- \\
130\end{array}$ & $\begin{array}{l}2.2- \\
2.6\end{array}$ & $<5$ & $<0.1 \mathrm{~g} / 24 \mathrm{~h}$ & & & \\
\hline
\end{tabular}




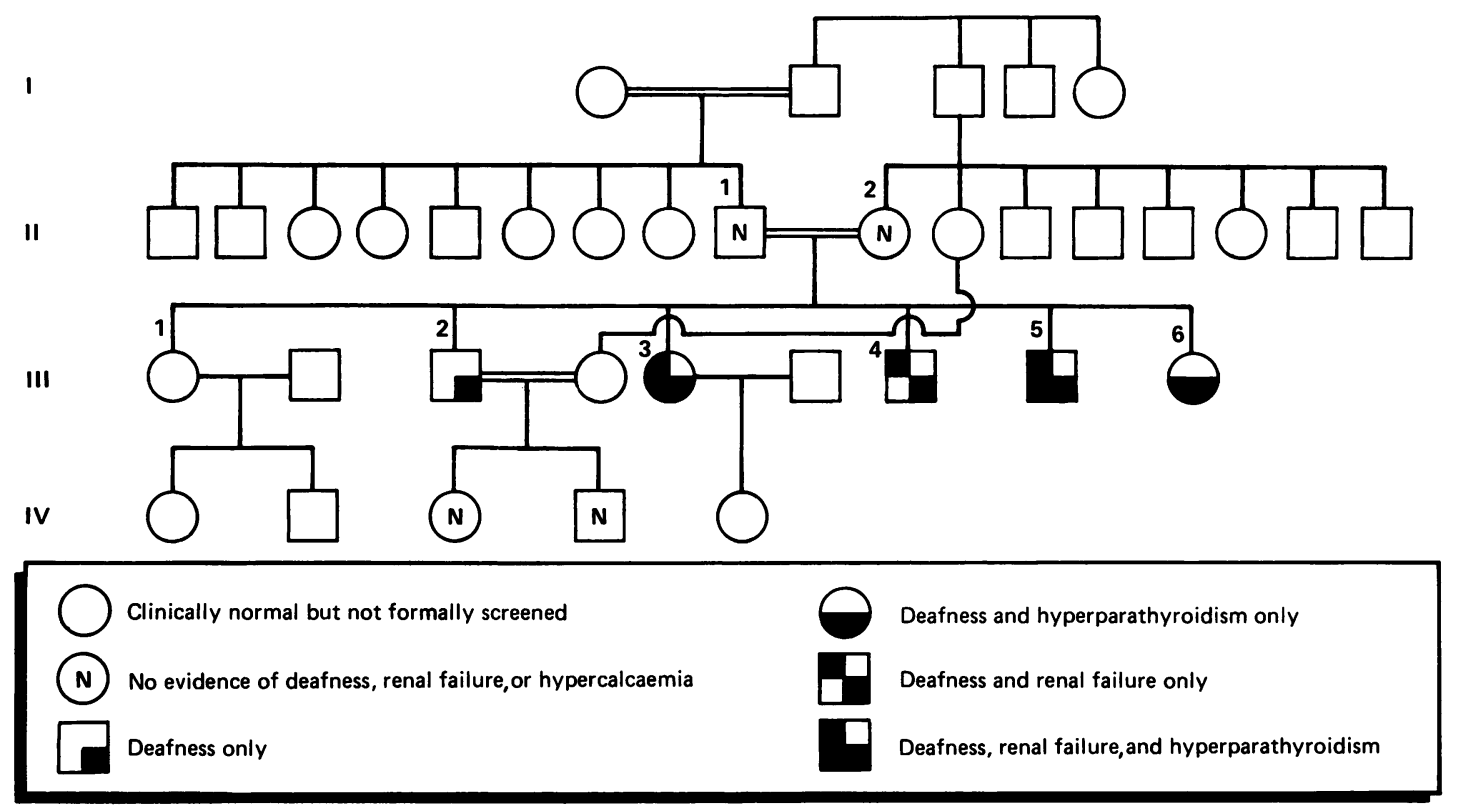

FIG 1 Family pedigree.

inclusions. In 1978 he failed a school hearing test. Audiogram indicated a $50 \mathrm{~dB}$ hearing loss in the range 1500 to $8000 \mathrm{~Hz}$. He was considered to have Alport's syndrome but it was noted that examination of his urine for red cells was repeatedly negative. Examination of his eyes was normal. His GFR continued to fall and in 1981, aged 17, he was referred for dialysis/transplantation. He now has a renal transplant which is functioning satisfactorily.

CASE III. 4

This 18 year old asymptomatic boy was investigated as a result of the discovery of renal failure and deafness in his younger brother (III.5). Investigations in 1978 showed the following: urea $12 \cdot 8$ $\mathrm{mmol} / \mathrm{l}$, creatinine $396 \mu \mathrm{mol} / \mathrm{l}$, calcium $1.41 \mathrm{mmol} / \mathrm{l}$, phosphate $1.69 \mathrm{mmol} / \mathrm{l}$, and alkaline phosphatase 58 IU/l. Urine examination showed protein ' ++ ' on stick testing but, as with his younger brother, no red cells. An attempt at renal biopsy was unsuccessful. Audiogram indicated a $70 \mathrm{~dB}$ hearing loss in the range 2000 to $8000 \mathrm{~Hz}$. Examination of his eyes was normal. His GFR fell inexorably over the next three years and at the age of 21 he was referred for dialysis/transplantation. Like his younger brother, he now has a satisfactorily functioning renal transplant.

CASE III. 3

A 22 year old sister was also investigated in 1978 as a result of the renal failure and deafness in III.5. She was found to have a $70 \mathrm{~dB}$ hearing loss in the range 4000 to $8000 \mathrm{~Hz}$. In 1981 she had an uneventful pregnancy during which she was normotensive, urea $6.5 \mathrm{mmol} / \mathrm{l}$. Interestingly, the plasma calcium was $2.84 \mathrm{mmol} / \mathrm{l}$ but no action appears to have been taken.

In 1984 she presented to her own doctor with a two month history of painful swollen ankles, urea $10.9 \mathrm{mmol} / \mathrm{l}$, creatinine $324 \mu \mathrm{mol} / \mathrm{l}$, creatinine clearance $14 \mathrm{ml} / \mathrm{min}$, and urine protein $0.55 \mathrm{~g} / 24 \mathrm{~h}$. Repeated urine examination failed to show any red cells, though occasionally white cells were seen. The plasma calcium was $3.84 \mathrm{mmol} / \mathrm{l}$, phosphate 1.13 $\mathrm{mmol} / \mathrm{l}$, alkaline phosphatase (bone isoenzyme) $1950 \mathrm{IU} / \mathrm{l}$, PTH $2.8 \mu \mathrm{g} / \mathrm{ml}$ (normal $<0 \cdot 50$ ), and $25-\mathrm{OH}$ vitamin D $32 \mathrm{nmol} / \mathrm{l}$ (normal range 15 to 100 ). Hand radiographs showed widespread phalangeal subperiosteal resorption (fig 2) with cysts typical of hyperparathyroidism. Thallium-technetium subtraction isotope scan showed enhanced uptake in the region of the right lower pole of the thyroid. Neck exploration showed three enlarged parathyroid glands, all of which were removed (weights $140 \mathrm{mg}$, $184 \mathrm{mg}$, and $565 \mathrm{mg}$ ). Histology indicated hyperplasia in all three and one contained an adenoma. Renal biopsy showed mesangial hypercellularity with focal basement membrane thickening and periglomerular fibrosis. There was marked chronic interstitial inflammation, tubular atrophy, and dilatation. 
Immunofluorescence for $\mathrm{C} 3, \mathrm{IgG}, \operatorname{IgA}, \operatorname{IgM}$, and fibrinogen was negative. Staining with antibody to glomerular basement membrane was negative.

After the parathyroidectomy, she was persistently hypocalcaemic and was treated with $1 \alpha-\mathrm{OH}$ vitamin D3 for six months. The plasma alkaline phosphatase fell from 720 to 174 IU/l. Later, in 1985, she became pregnant for the second time and in the sixth month she developed a mandibular mass extending from the incisors to the angle of the jaw. Histological examination showed a giant cell lesion which in the

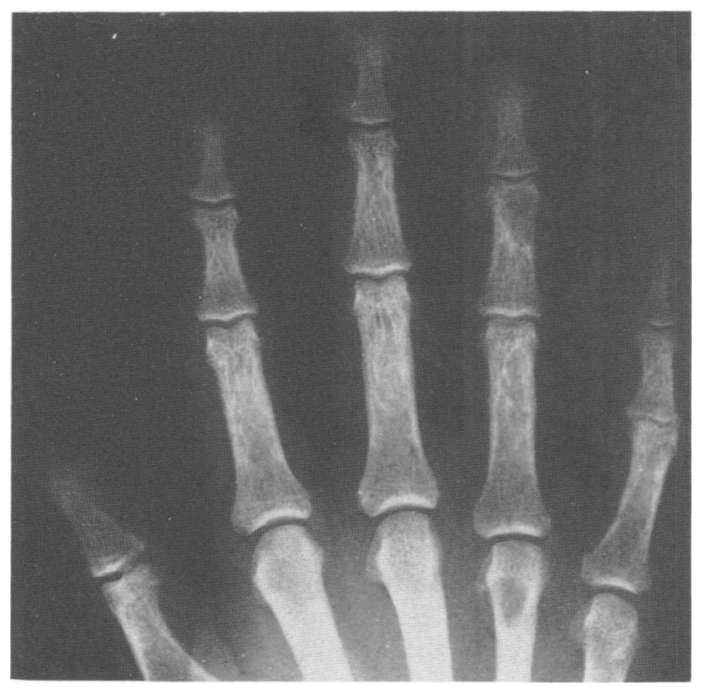

FIG 2 Hand radiograph showing phalangeal subperiosteal resorption and cysts in the middle phalanx and metacarpal of the ring finger. context of hyperparathyroidism was considered to be a brown cell tumour (fig 3 ). The plasma alkaline phosphatase had risen to $455 \mathrm{IU} / \mathrm{l}$, calcium $2 \cdot 25$ $\mathrm{mmol} / \mathrm{l}$, phosphate $2 \cdot 18 \mathrm{mmol} / \mathrm{l}$, and PTH $0.14 \mu \mathrm{g} / \mathrm{ml}$ (normal $<0 \cdot 50$ ). Delivery took place uneventfully at term without deterioration in GFR, urea 11.3 $\mathrm{mmol} / \mathrm{l}$ and creatinine $374 \mu \mathrm{mol} / \mathrm{l}$, though she was noted to be mildly hypertensive.

Thallium-technetium subtraction isotope scan suggested enhanced uptake in the left lower pole of the thyroid. A second neck exploration in January 1986 showed an adenoma weighing $900 \mathrm{mg}$. Postoperative hypocalcaemia necessitated reintroducing $1 \alpha-\mathrm{OH}$ vitamin D3. More recently, she was investigated for difficulty in conceiving further and was found to have serum prolactins of 1230 and 1325 $\mathrm{mU} / \mathrm{l}$. There was no galactorrhoea and $x$ rays of the pituitary fossa were normal as were her visual fields. It is possible that the raised prolactin concentration was a consequence of her severe renal failure. She was referred for dialysis/transplantation in 1987.

CASE III.6

The youngest member of the sibship, a sister aged 18, was investigated in 1987 and found to have a plasma calcium of $3.33 \mathrm{mmol} / \mathrm{l}$, phosphate 0.74 $\mathrm{mmol} / \mathrm{l}$, alkaline phosphatase $80 \mathrm{IU} / \mathrm{l}$, PTH $0.40 \mu \mathrm{g} / \mathrm{l}$ (normal $<0.50$ ), urea $5.5 \mathrm{mmol} / \mathrm{l}$, and creatinine 78 $\mu \mathrm{mol} / \mathrm{l}$. Audiograms indicated a $40 \mathrm{~dB}$ hearing loss in the range 2000 to $8000 \mathrm{~Hz}$. Urine examination was normal. A thallium-technetium subtraction scan was also normal.

CASE III.2

The oldest brother of case III.5 was known to have been profoundly deaf from an early age. When

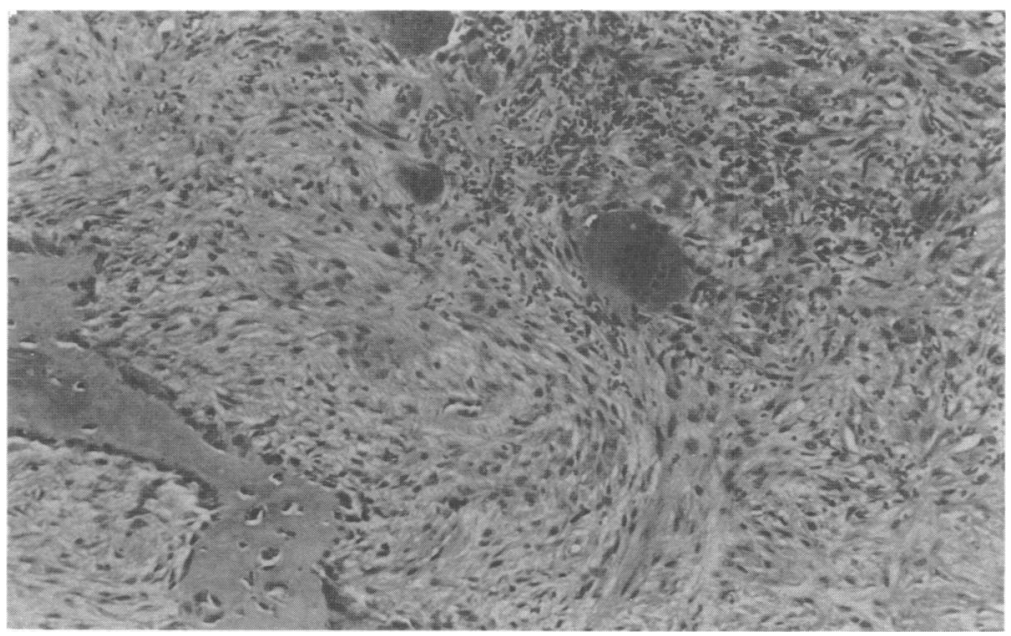

Fig 3 A bony trabecula (top right) surrounded by a fibroblastic stroma containing several multinucleate osteoclast giant cells. 
examined in 1987 at the age of 33 , his urea was 7.8 $\mathrm{mmol} / \mathrm{l}$, creatinine $97 \mu \mathrm{mol} / \mathrm{l}$, and calcium 2.29 $\mathrm{mmol} / \mathrm{l}$. He has married his cousin who has a urea of $3.6 \mathrm{mmol} / \mathrm{l}$, creatinine $67 \mu \mathrm{mol} / \mathrm{l}$, and calcium 2.4 $\mathrm{mmol} / \mathrm{l}$. They have two children below the age of four who are well, without evidence of renal failure or hearing loss.

\section{Other family members}

\section{CASE III.1}

The oldest sister is 34 and well. No detailed biochemistry is available. Examination of her urine was normal. Her audiogram was normal.

\section{CASE II. 1}

The father of cases III. 1 to 6 showed protein ' + ' on routine urine testing and $20 \mathrm{red}$ cells $/ \mu \mathrm{l}$. He was a non-insulin dependent diabetic and hypertensive. There was no clinical deafness. His urea and creatinine at the time of his death from ischaemic heart disease aged 57 were $5.7 \mathrm{mmol} / \mathrm{l}$ and 115 $\mu \mathrm{mol} / \mathrm{l}$ respectively.

\section{CASE II . 2}

The mother of cases III.1 to 6 was apparently normal and there was no evidence of renal failure (urea $7.8 \mathrm{mmol} / \mathrm{l}$, creatinine $96 \mu \mathrm{mol} / \mathrm{l}$ ) or deafness. The serum calcium was normal.

\section{Discussion}

The diagnosis of Alport's syndrome is usually made on clinical grounds, the features including sensorineural deafness, renal failure, and microscopic haematuria. There may also be ocular abnormalities and proteinuria occasionally developing into a frankly nephrotic state. It was Alport himself who stressed the importance of the association between deafness and microscopic haematuria in hereditary nephritis. ${ }^{2}$ In practice, affected subjects are often discovered by routine urine analysis. In a series of 58 children, 38 were detected by this means and 18 originally presented with gross haematuria. ${ }^{5}$ The nerve deafness is characterised by bilateral hearing loss maximal in the range 2000 to $8000 \mathrm{~Hz}$. Early loss of hearing is often accompanied by early deterioration of renal function and total deafness without renal failure is unusual. Renal failure can occur at a relatively young age and is commoner in boys than in girls. Among the 58 children mentioned above, three boys developed end stage renal failure before the age of nine and five others between the ages of nine and 16 . The only two girls with end stage renal failure were 18 and 24 years old. ${ }^{56}$

Classical Alport's syndrome is believed to be inherited as an $\mathrm{X}$ linked dominant. ${ }^{7}$ Males are, therefore, more severely affected than females. In occasional families an autosomal dominant form of inheritance is probable and this helps to explain the heterogeneity of the disease. ${ }^{6} 8$ There have also been reports of parental consanguinity and in such cases both male and female sibs had severe renal disease and nerve deafness. Inheritance in these families is thought to be autosomal recessive. ${ }^{8}$

In Alport's syndrome the renal biopsy can often establish the diagnosis. On light microscopy, however, the features are not usually diagnostic. Increased mesangial matrix, mesangial hypercellularity, tuft sclerosis, and occasionally focal segmental hypercellularity with crescents have been described. Occasionally foam cells are seen within the interstitium. Immunofluorescence is usually negative and there is often the specific feature in patients with Alport's syndrome that the glomerular basement membrane fails to react with antibody to glomerular basement membrane, as in case III. 3 in the family reported. Electron microscopy shows irregular thickening and splitting of the glomerular basement membrane in around $80 \%$ of patients. In case III.5 electron microscopy of the renal biopsy showed splitting of the basement membrane. In other words, in the two patients in whom there was renal histology, the appearances were compatible with Alport's syndrome.

Familial hyperparathyroidism without other endocrine abnormalities appears to be rare. In such families as have been described there appears to be an autosomal dominant form of inheritance. Histology of the parathyroid glands has shown either adenomas or hyperplasia. Law et $a l^{9}$ have reported three sibs with parathyroid adenomas. There was no parental consanguinity and screening of the extended family indicated no evidence of hyperparathyroidism or other endocrine disorder. There has also been a report of a family in which normocalcaemic first cousins had two offspring with severe hyperparathyroidism of neonatal onset. ${ }^{10}$

The family described in this paper quite clearly has a form of familial nephropathy. Alport's syndrome appeared to be a satisfactory diagnosis at first, because of the coexistence of renal failure and deafness. However, the lack of red cells in the urine of those sibs who reached end stage renal failure introduced an element of uncertainty, and the lack of significant proteinuria in these three subjects led to re-evaluation of the diagnosis. Certain other inconsistencies emerged, particularly from other family members. The oldest male sib had been severely deaf all his life having required a hearing aid for as long as he could remember; investigation of this sib showed no evidence of renal disease. This 
lack of renal disease would be unusual if the deafness were the result of Alport's syndrome. The parents of the sibs were first cousins; both had normal renal function, normal serum calcium, and normal hearing. The father's mild proteinuria was probably explained by diabetes mellitus. It was not possible to obtain plasma calcium and creatinine measurements from other family members, but there was no evidence of peptic ulcer disease, renal disease, renal stones, or hypertension to suggest subclinical hyperparathyroidism or other endocrinological abnormality. It should be pointed out that the serum prolactin of one of our patients (case III.3) was consistently less than $2000 \mathrm{mU} / \mathrm{l}$ and therefore unlikely to indicate a prolactinoma. The explanation for the raised prolactin was presumably her chronic renal failure. ${ }^{11}$

Three of the sibs described above had hyperparathyroidism and one of them (case III.6) had hypercalcaemia, hypophosphataemia, and an inappropriately high parathyroid hormone level. She has normal renal function and presumably her hyperparathyroidism is primary. Another sib (case III.3) had hypercalcaemia when she was pregnant at a time when her urea was $6.5 \mathrm{mmol} / \mathrm{l}$. Presumably, therefore, she also had parathyroid pathology before she developed renal failure. Case III.5 presented at the age of nine years with a plasma calcium of $2.9 \mathrm{mmol} / \mathrm{l}$ at a time when his urea was 10.4 $\mathrm{mmol} / \mathrm{l}$ and creatinine $310 \mu \mathrm{mol} / \mathrm{l}$. It appears from the above that in all three subjects the hyperparathyroidism may have developed at a time when renal function was normal, that is, they had primary hyperparathyroidism rather than the secondary hyperparathyroidism typical of longstanding renal failure.

We have been able to find only one report linking renal disease, deafness, and parathyroid disease. ${ }^{12}$ Four sibs were born with severe nephrotic syndrome, sensorineural deafness, and hypoparathyroidism. It is clear that this report is describing a condition quite different from that seen in our family.

In summary, members of the above family have shown a strong tendency to develop renal failure, deafness, and hyperparathyroidism. Since the parents did not manifest any of these abnormalities and were first cousins, it is likely that the clinical features described above are explained by an autosomal recessive mode of inheritance involving only a single gene. It is just possible that in this inbred family two autosomal recessive disorders have occurred together. The family discussed in this report stresses the importance of resolving the heterogeneity of syndromes with deafness and nephritis and distinguishing these from Alport's syndrome, which has been provisionally mapped to the $\mathrm{Xq} 21$ region. ${ }^{13}$

We would like to thank Dr F A Flinter for her comments, the Department of Medical Illustration at St George's and St James's Hospitals for preparing the prints and figures, and Mrs S Willoughby for preparing the manuscript.

\section{References}

${ }^{1}$ Hurst AS. Hereditary familial congenital haemorrhagic nephritis occurring in sixteen individuals in three generations. Guy's Hosp Rep 1923;73:368-70.

2 Alport AC. Hereditary familial congenital haemorrhagic nephritis. Br Med J 1927;i:504-6.

${ }^{3}$ Muckle TJ, Wells MV. Urticaria, deafness and amyloidosis: a new heredo-familial syndrome. $Q J$ Med 1962;31:235-48.

4 Braun FC, Bayer JF. Familial nephrosis associated with deafness and congenital urinary tract anomalies in siblings. $J$ Pediatr 1962;60:33-41.

5 Gubler M, Levy M, Broyer M, et al. Alport's syndrome: a report of 58 cases and a review of the literature. Am J Med 1981;70:493-505

6 Grunfeld JP. The clinical spectrum of hereditary nephritis. Kidney Int 1985;27:83-92.

7 O'Neil WM Jr, Atkin CL, Bloomer HA. Hereditary nephritis: a re-examination of its clinical and genetic features. Ann Intern Med 1978;88:176-82.

${ }^{8}$ Feingold J, Bois E, Chompret A, Broyer M, Gubler MC, Grunfeld JP. Genetic heterogeneity of Alport's syndrome. Kidney Int 1985;27:672-7.

9 Law WM, Hodgson SF, Heath H. Autosomal recessive inheritance of familial hyperparathyroidism. N Engl J Med 1983;309: 650-2.

${ }^{10}$ Hillman DA, Scriver CR, Pedius S, Shragovitch I. Neonatal familial primary hyperparathyroidism. $N$ Engl J Med 1964;270: 483-90.

11 Edwards CRW, Feek CM. Prolactinoma: a question of rational treatment. Br Med J 1981;283:1561-2.

12 Barakat AY, D'Albora JB, Martin MM, Jose PA. Familial nephrosis, nerve deafness and hypoparathyroidism. J Pediatr 1977;91:61-4.

13 Flinter FA, Bobrow M, Chantler C. Alport's syndrome or hereditary nephritis. Pediatr Nephrol 1987;1:438-40.

Correspondence to Dr J B Eastwood, Department of Medicine, St George's Hospital Medical School, Cranmer Terrace, London SW17 0RE. 